\title{
Effectiveness of different investigation procedures in detecting anthropogenic impacts on coralligenous assemblages
}

\author{
Luigi Piazzi ${ }^{1}$, David Balata ${ }^{2}$, Enrico Cecchi ${ }^{3}$, Paola Gennaro ${ }^{4}$, Fabrizio Serena ${ }^{3}$ \\ ${ }^{1}$ Dipartimento di Scienze della Natura e del Territorio, Università di Sassari, Via Piandanna 4, 07100 Sassari, Italy. \\ ${ }^{2}$ Tenuta San Beda, via Carmignani 18, 55015 Montecarlo (Lu), Italy. \\ ${ }^{3}$ Regional Agency for the Tuscan Environment protection (ARPAT), Via Marradi 114, 57126 Livorno, Italy. \\ ${ }^{4}$ Italian National Institute for Environmental Protection and Research (ISPRA ex ICRAM), Via di Castel Romano 100, \\ 00128, Roma, Italy. E-mail: paola.gennaro@isprambiente.it
}

\begin{abstract}
Summary: Coralligenous habitat is one of the most important and sensitive habitats of the Mediterranean Sea and several different sampling procedures are currently used in the ecological investigations of coralligenous assemblages. This study aimed to assess the efficacy of different methods in detecting anthropogenic impacts on coralligenous habitat. In particular, the choice of sampling methods, the level of taxonomic resolution, the sampling area, the number of replicates and the spatial scales for detecting possible impacts were evaluated. Results showed that photographic samples larger than $1800 \mathrm{~cm}^{2}$, numbers of replicates larger than 10, the use of taxa and morphological groups as assemblage descriptors, and sampling designs with a high replication at small spatial scales are a valid methodological procedure in impact evaluation studies based on coralligenous assemblages.
\end{abstract}

Keywords: coralligenous habitat; sampling methods; spatial scales; number of replicates; sampling surface; Mediterranean Sea.

Efectividad de los diferentes procedimientos de muestreo para detectar el impacto antrópico sobre la comunidad de coralígeno

Resumen: El hábitat coralígeno es uno de los más importantes y sensibles del mar Mediterráneo y actualmente se pueden aplicar varios métodos de muestreo en las investigaciones ecológicas de las comunidades macroalgales coralígenas. El objetivo del presente estudio es evaluar la efectividad de los diferentes procedimientos para detectar el impacto antrópico sobre el hábitat de coralígeno. Se evaluaron en particular la elección de los métodos de muestreo, el nivel de resolución a la que los taxones tienen que ser identificados, la superficie de muestreo, el número de repeticiones y las escalas espaciales adecuadas para la investigación de los posibles impactos. Los resultados indican que muestras fotográficas de $1800 \mathrm{~cm}^{2}$, un número de repeticiones mayor que 10 , el uso de taxones y grupos morfológicos como descriptores y diseños de muestreo con una alta replicación asociada a pequeñas escalas espaciales pueden representar elementos metodológicos válidos en los estudios de evaluación de impacto basados en las comunidades coralígenas.

Palabras clave: hábitat coralígeno; métodos de muestreo; escalas espaciales; número de repeticiones; superficie de muestreo; Mar Mediterráneo.

Citation/Como citar este artículo: Piazzi L., Balata D., Cecchi E, Gennaro P., Serena F. 2014. Effectiveness of different investigation procedures in detecting anthropogenic impacts on coralligenous assemblages. Sci. Mar. 78(3): 319-328. doi: http://dx.doi.org/10.3989/scimar.03989.28A

Editor: J. Garrabou.

Received: December 3, 2013. Accepted: April 8, 2014. Published: July 28, 2014.

Copyright: (c) 2014 CSIC. This is an open-access article distributed under the Creative Commons Attribution-Non Commercial Lisence (by-nc) Spain 3.0.

\section{INTRODUCTION}

The relevance of sampling procedures in marine ecology is widely recognized and determining the sampling methods most responsive to the questions/objectives plays a fundamental role in research success (BenedettiCecchi et al. 1996). The choice of spatial scales, the definition of sampling effort and the identification of appropriate descriptors are major problems in defining suitable sampling methods in ecological studies. 
Natural variability of marine benthic assemblages is scale-dependent (Underwood and Chapman 1996, Terlizzi et al. 2007) and the lack of knowledge concerning the spatial patterns of organism distribution makes it difficult to interpret results of environmental monitoring surveys and impact evaluation studies (Hewitt et al. 2001, Bishop et al. 2002, Fraschetti et al. 2005). The main goals for ecologists are to understand spatial patterns of variability in populations and assemblages and to identify the main scales of variability (Benedetti-Cecchi 2001a) in order to plan appropriate designs and to optimize environmental sampling programmes (Underwood 1993, Benedetti-Cecchi 2001b, Benedetti-Cecchi et al. 2003).

Another important consideration concerns sampling procedures in marine habitats. Destructive methods are widely utilized and recognized as suitable for describing benthic assemblages in relation to the assessment of patterns of diversity and detection of rare species (Piazzi et al. 2004, 2010, 2011). However, they may be difficult to apply in particular habitats, such as caves or deep water, or unsuitable for use in protected areas. In these cases, photographic techniques can be used to quickly obtain a suitable quantity of samples that may be analysed successively (Garrabou et al. 2002, Parravicini et al. 2009, 2010a, Deter et al. 2012b). Like all visual methods, photographic techniques do not permit a complete species identification, so grouping species in easily identifiable categories is necessary for the assemblage analysis.

Identifying suitable assemblage descriptors that are sensitive to human-induced stress is very important in impact evaluation studies, because it optimizes sampling efforts and allows representative patterns of assemblage variability to be obtained (Chapman 1998). According to the objectives of the study, the grouping of species sharing the same general taxonomic or morphological traits may be advantageous for many reasons. Species identification requires a high level of taxonomic expertise, so the time and cost are far greater than for a reduced taxonomic level of resolution (Terlizzi et al. 2003). Lower sorting costs may make it possible to analyse the high number of samples needed to accurately describe habitat variability. A widespread strategy used in studies concerning the marine zoobenthos is to group organisms at taxonomic levels higher than species (De Biasi et al. 2003, Hirst 2006), but this approach is not suitable for macroalgal assemblages (Hirst 2006) because species belonging to the same supra-specific taxon (genus or family) may show different ecological characteristics (Balata et al. 2011). A morpho-functional approach, grouping species with similar morphological traits and a similar response to environmental conditions, is widely used to describe both animals and macroalgal assemblages (Jackson 1979, Littler and Littler 1980, Steneck and Dethier 1994, Cocito et al. 1997, Konar and Iken 2009, Parravicini et al. 2010a, 2013). Despite the loss of information in this approach (Phillips et al. 1997), analysis of morpho-functional groups may detect impacts with an efficiency similar to that obtained by species analysis (Balata et al. 2011).
Coralligenous habitats develop on deep subtidal rocky bottoms in the Mediterranean Sea, where they are one of the most important habitats in size, biodiversity and role in $\mathrm{CO}_{2}$ dynamics (Laborel 1961, 1987, UNEP 2007). Coralligenous habitats are constituted primarily by calcareous structures edified by Rhodophyta belonging to Corallinales and Peyssonneliales and secondarily by several sessile animals, mostly Cnidaria, Polychaeta and Bryozoa (Ballesteros 2006). The ecological importance of coralligenous habitats and their scientific and biodiversity interest are recognized by international conventions (e.g. Barcelona 1995), so they can be considered one of the most important "special habitat types" that should be assessed under the Marine Strategy Framework Directive (EC 2008) through accurate monitoring plans. The development of monitoring programmes needs the assessment of effective sampling designs and methods in order to optimize efforts and to give appropriate responses to ecological problems. Coralligenous assemblages have been widely studied in relation to species composition (Laubier 1966, Hong 1982, Garrabou et al. 2002, Casellato and Stefanon 2008, Piazzi et al. 2010), patterns of spatial and temporal variability (Ferdeghini et al. 2000, Cocito et al. 2002, Piazzi et al. 2004, Balata et al. 2005, 2006a, 2006b, Virgilio et al. 2006, Piazzi and Balata 2011, Ponti et al. 2011), and responses to anthropogenic impacts (Hong 1983, Garrabou et al. 1998, Balata et al. 2007a, 2007b, Piazzi et al. 2007, 2011, 2012, Roghi et al. 2010). Recently, several methods have been developed to assess ecological quality of coralligenous assemblages through a non-destructive approach (Kipson et al. 2011, Deter et al. 2012a, Gatti et al. 2012). In this context, a minimal area was defined for photographic samples (Kipson et al. 2011, Teixido et al. 2013). However, several aspects necessary to assess the suitability of the sampling methods, such as the comparison between destructive and non-destructive approaches or the spatial scales to be examined, were not evaluated.

The aim of the present study was to contribute to the assessment of the most effective procedures for detecting effects of impacts on Mediterranean coralligenous habitats. In particular, the choice of sampling methods, the level of taxonomic resolution, the sampling area, the number of replicates and the proper spatial scales to study were evaluated. To achieve these objectives, multi-factorial sampling designs were used to find spatial scales with high variability and to compare results obtained with different descriptors, different numbers of replicates and different sampling areas.

\section{MATERIALS AND METHODS}

The study was carried out in the summer months along the coasts of Tuscany (northwestern Mediterranean Sea, Italy), on rocky vertical bottoms at 30-35 $m$ depth. This depth was chosen because macroalgal coralligenous assemblages of this depth range are the most representative of the geographical area considered, in terms of structure and response to alterations of environmental conditions (Piazzi and Balata 2011). 


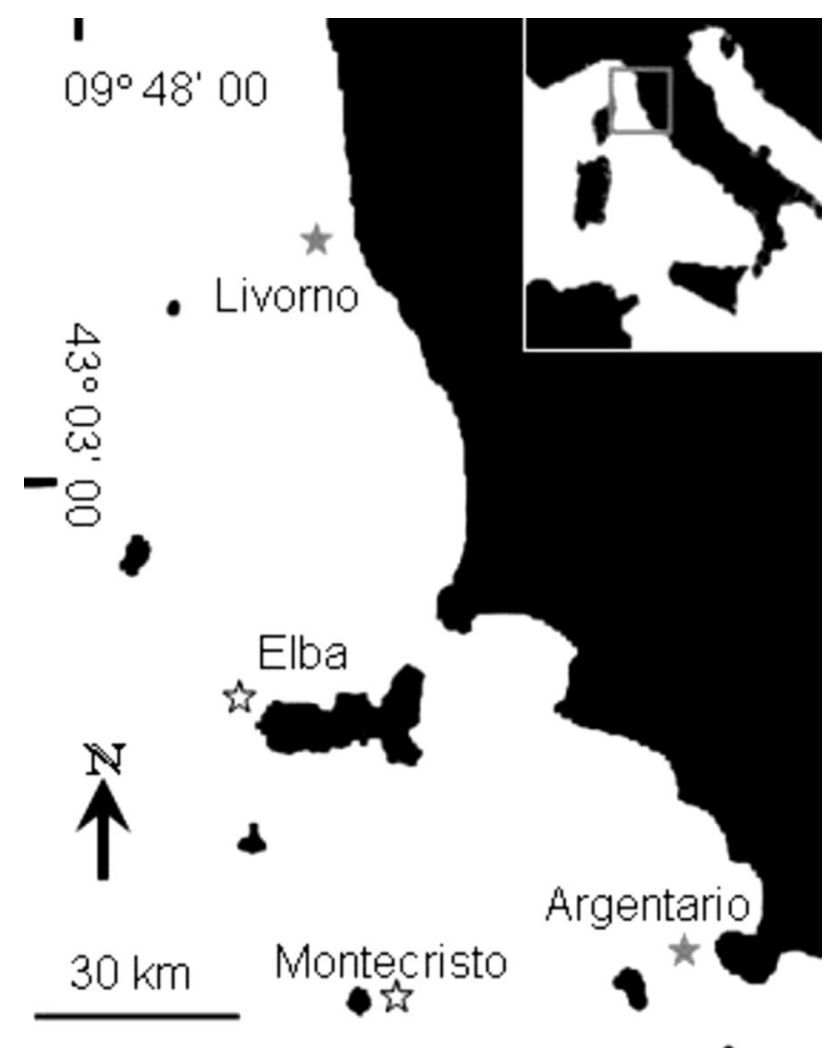

Fig. 1. - Map of the study sites. White stars, reference sites; grey stars, stressed sites.

\section{Comparison between sampling methods and as- semblage descriptors}

Two different ecological conditions were considered: a stressed condition consisting of marine areas affected by urban and/or industrial discharges and high sedimentation rates; and a reference condition consisting of areas subjected to absence of, or very minor, stress (Annex I, EC 2000). For each condition, two sites several kilometres from each other were chosen along the Tuscany coasts (Fig. 1) and in each site two areas hundreds of metres apart were studied. In each area of about $25 \mathrm{~m}^{2}$, three destructive samples and three photographic samples were collected. Both destructive and photographic samples covered a bottom area of $400 \mathrm{~cm}^{2}$, which is considered the minimum area for studying Mediterranean rocky macroalgal assemblages (Boudouresque 1971).

Destructive samples were collected by scraping the bottom with a hammer and a chisel, all sessile organisms were identified and the abundance of each sessile species was expressed as percentage cover of the sample area.

In the photographic samples, the percentage cover of the main taxa or morphological groups was evaluated using the "Image J" software (http://rsbweb.nih. gov/ij/download.html, Cecchi et al. 2010). In these samples, animals and seaweeds easily recognizable by visual census were considered at species or genus level, while taxa not easily recognizable were grouped into the following morphological groups: encrusting
Corallinales, articulated Rhodophyta, algal turf, erect corticated algae, flattened Rhodophyta with cortication, madrepores, hydroids, encrusting and erect bryozoans, massive encrusting sponges and erect sponges.

To compare the efficiency of different methods (destructive vs. photographic) and the suitability of assemblage descriptors (species vs. taxa/morphological groups) in detecting responses to environmental stress, data obtained by analysing photographic samples, data obtained by analysing destructive samples at the species level and data obtained through a taxa/morphological groups analysis of assemblages carried out according to the photographic approach on the same destructive samples were analysed by permutational multivariate analysis of variance (PERMANOVA, Primer v6 program including the add-on package PERMANOVA plus, Anderson 2001) performed on a Bray-Curtis dissimilarity matrix of untransformed data (number of permutations 999). The Monte-Carlo procedure was used when the number of possible permutations was too low. A three-way model was used with Condition (reference vs. stressed) as a fixed factor, Site (2 levels) as a random factor nested in Condition and Area (2 levels) as a random factor nested in Site.

\section{Comparison between sampling areas and number of replicates}

In each of the two reference sites, 10 photographic samples of $400 \mathrm{~cm}^{2}$ and 10 photographic samples of $1875 \mathrm{~cm}^{2}$ (fitted with a frame $50 \times 37.5 \mathrm{~cm}$ ) were collected. Sampling surface and number of replicates were chosen according to pilot studies (Acunto 2000, Acunto et al. 2001). Abundance of taxa/morphological groups was obtained through the same methods described above. Data were analysed by a two-way PERMANOVA analysis, with Area $\left(400 \mathrm{~cm}^{2}\right.$ vs. 1875 $\mathrm{cm}^{2}$ ) as a fixed factor and Site (2 levels) as a random factor nested in Area.

At each of the two reference sites and two stressed sites, 20 photographic samples of $1875 \mathrm{~cm}^{2}$ were collected. To compare the effectiveness of different sampling areas in detecting assemblage responses to stressors and in describing spatial patterns of variability, data obtained with $30,25,20,15,10$ and 5 replicates for each site were analysed by two-way PERMANOVA with Condition (reference vs stressed) as a fixed factor and Site (2 levels) as a random factor nested in Condition.

\section{Spatial variability of coralligenous assemblages}

Two pristine or minor stressed sites were selected along the Tuscany coasts and, at each site, two locations several kilometres apart were chosen; at each location, two areas hundreds of metres apart were selected and 15 photographic samples of $1875 \mathrm{~cm}^{2}$ were collected in each area about $1 \mathrm{~m}$ from each other.

To determine patterns of variability at each of the chosen spatial scales, data were analysed by a fourway PERMANOVA analysis, with Site (2 levels) as a random factor, Location (2 levels) as a random factor 

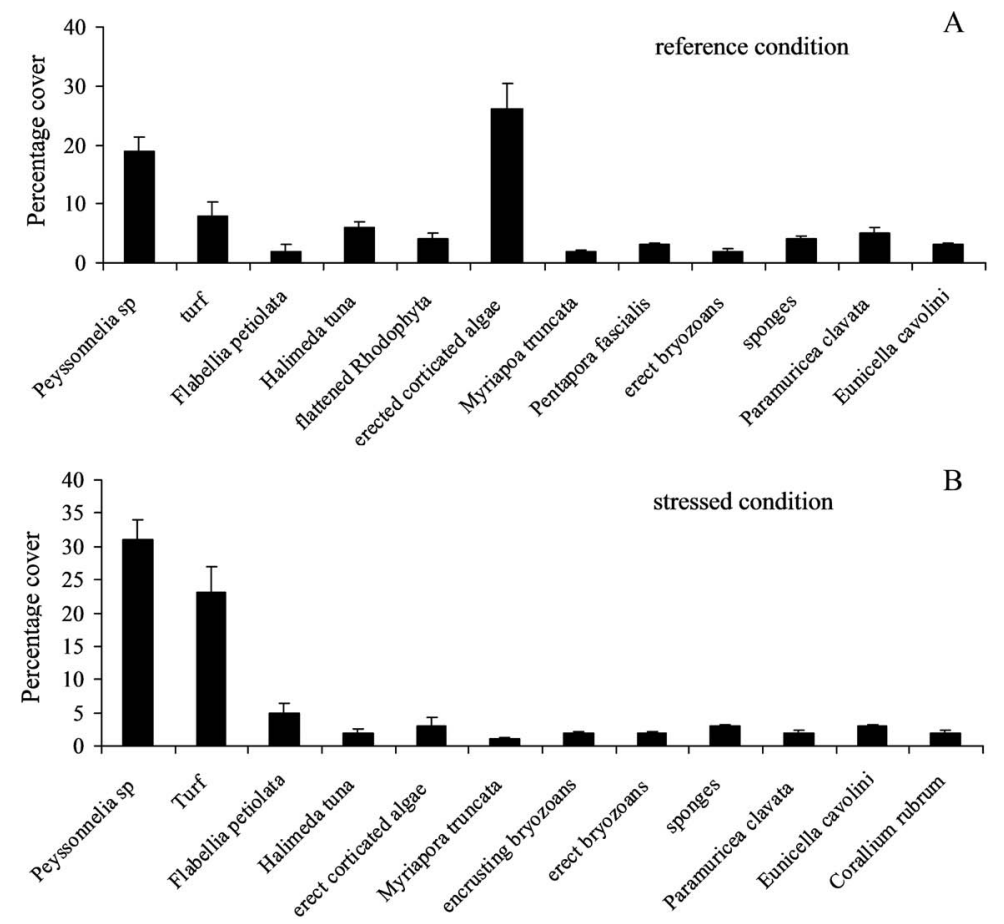

FIG. 2. - Percentage cover (mean \pm SE, $n=12$ ) of the main taxa/morphological groups (mean percentage cover greater than 2 ) in coralligenous assemblages. Encrusting Corallinales showed a cover of $100 \%$ and they are not considered in the figures.

nested in Site and Area (2 levels) as a random factor nested in Location. The pseudo-variance components were calculated for each spatial scale: site, location, area and sample.

\section{RESULTS}

\section{Comparison between sampling methods and as- semblage descriptors}

A total of 123 taxa were identified by destructive samples (Appendix 1 with nomenclature authority). In photographic samples, 18 taxa and 10 morphological groups were considered (Appendix 1).

The studied assemblages were characterized by a stratified structure: encrusting Corallinales, mostly Mesophyllum alternans, Mesophyllum macroblastum, Lithothamnion philippii, Lithophyllum pustulatum and Lithophyllum stictaeforme, completely covered the rocky bottom, creating a secondary substrate colonized by prostate, intermediate and erect layers.

In reference condition the prostrate layer was mostly characterized by the macroalgae, Palmophyllum crassum and Peyssonnelia spp., while the encrusting bryozoan Schizobrachiella sanguinea, the erect bryozoan Cradoscrupocellaria reptans, the cnidarians Parazoanthus axinellae and Leptopsammia pruvoti and the sponges Penares euastrum, Agelas oroides and Dictyonella incisa were also common with variable abundance. The most common species in the intermediate layer were Halimeda tuna, Flabellia petiolata, erect corticated forms (Osmundaea pelagosae and Laurencia chondrioides) and flattened Rhodophyta with cortication (Meredithia microphylla and Acrodiscus vidovichii) among macroalgae and the erect bryozoans Pentapora fascialis, Myriapora truncata and Smittina cervicornis among animals (Fig. 2). The erect layer was characterized by the gorgonians Paramuricea clavata and Eunicella cavolini.

At all the stressed sites, several turf-forming macroalgae increased their abundance (Womersleyella setacea, Anthithamnion piliferum, Heterosiphonia crispella, Polysiphonia subulifera and Pseudochlodesmis furcellata), while several erect and prostrate macroalgae (Halimeda tuna, Flabellia petiolata, Meredithia microphylla, Osmundaea pelagosae, Zanardinia typus) and bryozoans (Pentapora fascialis and Smittina cervicornis) decreased (Fig. 2).

Results of PERMANOVA analyses showed significant differences between reference and stressed conditions for all three approaches used: photographic samples, destructive samples analysed at species level, and destructive samples analysed at taxa/morphological groups level. A significant variability between areas was only detected in the destructive samples (Table 1).

\section{Comparison between sampling areas and number of replicates}

PERMANOVA analysis detected no significant differences between samples collected using different areas (Table 2). The SIMPER test highlighted a dissimilarity of 52.3 between areas; differences were mostly related to erect corticated algae, which were overestimated in $400 \mathrm{~cm}^{2}$ samples, and Gorgonacea, which showed an opposite pattern (Table 3).

A similar pattern of spatial variability of assemblages was obtained by analysing $10,15,20,25$ and 30 replicates, but the results obtained using the 5 replicates approach gave a different pattern (Table 4). 
Table 1. - Results of PERMANOVA analyses on coralligenous assemblages subjected to different conditions obtained through destructive and photographic sampling methods. Results of the destructive samples referred both to the species and morphological groups levels of determination. Significant effects are in bold.

\begin{tabular}{|c|c|c|c|c|c|c|c|c|c|c|}
\hline \multirow[b]{2}{*}{ Source } & \multicolumn{4}{|c|}{ Destructive species level } & \multicolumn{3}{|c|}{ Destructive morphological groups level } & \multicolumn{3}{|c|}{ Photographic morphological groups level } \\
\hline & df & MS & Pseudo-F & $\mathrm{P}($ perm $)$ & MS & Pseudo-F & $P($ perm $)$ & MS & Pseudo-F & $\mathrm{P}($ perm $)$ \\
\hline Condition $=\mathrm{C}$ & 1 & 7377.3 & 2.49 & 0.047 & 7823.2 & 3.95 & 0.036 & 7398.4 & 7.54 & 0.022 \\
\hline $\operatorname{Site}(C)=S(C)$ & 2 & 2956.9 & 0.85 & 0.618 & 1979.3 & 1.10 & 0.388 & 968.8 & 1.11 & 0.392 \\
\hline $\operatorname{Area}(\mathrm{S}(\mathrm{C}))$ & 4 & 3452.6 & 1.65 & 0.039 & 1792.3 & 1.93 & 0.031 & 862.7 & 2.10 & 0.069 \\
\hline Residual & 16 & 2082.6 & & & 928.6 & & & 408.9 & & \\
\hline Total & 23 & & & & & & & & & \\
\hline
\end{tabular}

Table 2. - Results of PERMANOVA analysis comparing the morphological groups composition and abundance datasets obtained through the photographic method and using different sampling areas $\left(400 \mathrm{~cm}^{2}\right.$ and $\left.1875 \mathrm{~cm}^{2}\right)$.

\begin{tabular}{lcccc}
\hline Source & df & MS & Pseudo-F & P (perm) \\
\hline Area $=$ A & 1 & 4555.9 & 1.72 & 0.211 \\
Site $=$ S & 2 & 2642.6 & 1.92 & 0.050 \\
Residual & 36 & 1376.2 & & \\
Total & 39 & & & \\
\hline
\end{tabular}

Table 3. - Results of SIMPER test showing taxa/groups responsible for differences between patterns obtained with $400 \mathrm{~cm}^{2}$ and 1875 for differences between patterns obtained witl
\[ \mathrm{cm}^{2} \text { sampling areas. } \]

\begin{tabular}{lccc}
\hline Taxa/groups & $\begin{array}{c}400 \mathrm{~cm}^{2} \\
\text { cover }\end{array}$ & $\begin{array}{c}1875 \mathrm{~cm}^{2} \\
\text { cover }\end{array}$ & Contrib. \% \\
\hline Algal turf & 49.04 & 40.03 & 26.5 \\
Peyssonnelia spp. & 19.6 & 22.91 & 20.59 \\
Erect corticated algae & 12.77 & 0.54 & 12.61 \\
Encrusting Corallinales & 4.33 & 12.31 & 11.64 \\
Eunicella cavolini & 0.63 & 4.86 & 4.69 \\
Flabellia petiolata & 2.43 & 4.23 & 3.78 \\
Encrusting sponges & 1.03 & 3.1 & 3.62 \\
Halimeda tuna & 3.4 & 0.28 & 3.47 \\
Erect bryozoans & 0.13 & 3.01 & 2.94 \\
Reteporella spp. & 2.2 & 1.13 & 2.89 \\
\hline
\end{tabular}

\section{Spatial variability of coralligenous assemblages}

PERMANOVA analysis showed significant differences in coralligenous assemblages among areas, while differences between sites and locations were not significant (Table 5).

The pseudo-variance components showed the highest variability at the smallest spatial scales (area and sample), whereas the variability at the intermediate spatial scales (Location) was undetectable (Fig. 3).
Table 5. - Results of PERMANOVA analysis on morphological groups composition and abundance of coralligenous assemblages obtained with the photographic method applied at different spatial scales. Significant effects are in bold.

\begin{tabular}{lcccc}
\hline Source & df & MS & Pseudo-F & P(perm) \\
\hline Site $=$ S & 1 & 27446 & 3.09 & 0.088 \\
Location (A) = L(A) & 2 & 8879 & 0.94 & 0.477 \\
Area (L(A)) & 4 & 9376 & 9.78 & $\mathbf{0 . 0 0 1}$ \\
Residual & 112 & 958 & & \\
Total & 119 & & & \\
\hline
\end{tabular}

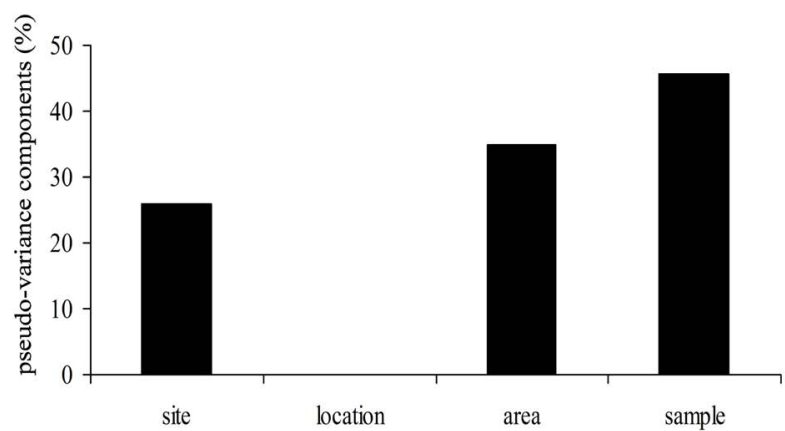

FIG. 3. - Percentage of pseudo-variance components at different spatial scales

\section{DISCUSSION}

The results of this study comparing different sampling procedures commonly used in the ecological investigation of coralligenous habitats provided indications about the method that could be most suitable for detecting changes in the structure of assemblages subjected to different levels of stress.

Both destructive and photographic methods detected significant differences between conditions and the

Table 4. - Results of PERMANOVA analyses on morphological groups abundance and composition datasets obtained through the photographic method with different numbers of replicates $(5,10,15,20,25$ and 30). MC, Monte-Carlo procedure. Significant effects are in bold.

\begin{tabular}{|c|c|c|c|c|c|c|c|c|}
\hline Source & $\mathrm{df}$ & MS & Ps-F & $\mathrm{P}(\mathrm{MC})$ & $\mathrm{df}$ & MS & Ps-F & $\mathrm{P}(\mathrm{MC})$ \\
\hline $\begin{array}{l}\text { Condition = C } \\
\text { Site }(\mathrm{C}) \\
\text { Residual } \\
\text { Total }\end{array}$ & $\begin{array}{c}1 \\
2 \\
16 \\
19\end{array}$ & $\begin{array}{l}5 \mathrm{r} \\
18991 \\
2942 \\
1415\end{array}$ & $\begin{array}{r}\text { tes } \\
6.45 \\
2.07\end{array}$ & $\begin{array}{l}\mathbf{0 . 0 2 4} \\
0.097\end{array}$ & $\begin{array}{c}1 \\
2 \\
36 \\
39\end{array}$ & $\begin{array}{l}10 \mathrm{r} \\
31967 \\
6191 \\
1572\end{array}$ & $\begin{array}{r}\text { es } \\
5.16 \\
3.93\end{array}$ & $\begin{array}{l}\mathbf{0 . 0 3 0} \\
\mathbf{0 . 0 0 1}\end{array}$ \\
\hline $\begin{array}{l}\text { Condition = C } \\
\text { Site }(C) \\
\text { Residual } \\
\text { Total }\end{array}$ & $\begin{array}{c}1 \\
2 \\
56 \\
59\end{array}$ & $\begin{array}{c}55967 \\
5079 \\
1580\end{array}$ & $\begin{array}{c}11.01 \\
3.21\end{array}$ & $\begin{array}{l}\mathbf{0 . 0 0 5} \\
\mathbf{0 . 0 0 8}\end{array}$ & $\begin{array}{c}1 \\
2 \\
76 \\
79\end{array}$ & $\begin{array}{l}20 \mathrm{r} \\
75768 \\
9975 \\
1577\end{array}$ & $\begin{array}{l}\text { es } \\
7.59 \\
6.32\end{array}$ & $\begin{array}{l}0.007 \\
0.001\end{array}$ \\
\hline $\begin{array}{l}\text { Condition = C } \\
\text { Site }(C) \\
\text { Residual } \\
\text { Total }\end{array}$ & $\begin{array}{c}1 \\
2 \\
96 \\
99\end{array}$ & $\begin{array}{r}25 \\
83417 \\
12967 \\
1635\end{array}$ & $\begin{array}{l}\text { ates } \\
64.33 \\
79.26\end{array}$ & $\begin{array}{l}\mathbf{0 . 0 0 8} \\
\mathbf{0 . 0 0 1}\end{array}$ & $\begin{array}{c}1 \\
2 \\
116 \\
119\end{array}$ & $\begin{array}{l}30 \mathrm{r} \\
92409 \\
14807 \\
1673\end{array}$ & $\begin{array}{l}\text { es } \\
62.40 \\
88.47\end{array}$ & $\begin{array}{l}0.010 \\
0.001\end{array}$ \\
\hline
\end{tabular}


same differences were observed when the destructive samples were analysed at the species level. These results, obtained considering both macroalgae and sessile animals, are in agreement with those highlighted by the comparison of macroalgal species and morphological groups chosen as descriptors of assemblages subjected to different stressors (Balata et al. 2011). Compared with the species level approach of the destructive method, loss of information concerning biodiversity assessment and occurrence of rare species due to the use of the photographic method seemed to be negligible for the purposes of the impact evaluation studies.

These findings suggest that the use of photographic techniques and the taxa/morphological groups approach may be a suitable and cost-effective method for studying coralligenous assemblages, in particular in monitoring programmes and environmental impact assessments; in fact, in these latter cases it is important to detect the early stages of environmental changes using procedures that allow a large number of samples to be examined in a limited time. Moreover, a non-destructive approach is suitable for sampling this particularly sensitive habitat, is the only one applicable in marine protected areas and is surely in line with the recent European Framework Directives.

The minimum area considered for studying rocky sessile assemblages in the Mediterranean Sea is 400 $\mathrm{cm}^{2}$, but this area was obtained through destructive sampling of macroalgal assemblages collected in the shallow subtidal systems (Boudouresque 1971), so it is not suitable for studying coralligenous assemblages with photographic methods. In fact, the abundance of large colonial animals in coralligenous habitats may be underestimated if small sampling areas are used. Although the results of the present study are limited to only two sampling areas, they showed no significant differences between data obtained with sampling areas of 400 and $1878 \mathrm{~cm}^{2}$. However, a dissimilarity of 52.3 was detected and several taxa/morphological groups were over- or underestimated using replicates of 400 $\mathrm{cm}^{2}$. A larger area may be more suitable for describing coralligenous assemblages through photographic methods (Bianchi et al. 2004). Also, the number of replicates is an important factor for coralligenous habitats. In fact, great small-scale variability has been described for this system (Piazzi et al. 2004, Balata et al. 2005) and an appropriate number of replicates is necessary to separate patterns of natural variability from those caused by external factors. In the present study, no differences in results were found using 10, 15, 20, 25 and 30 replicates, and 5 replicates was insufficient to describe the variability of the system. A larger number of replicates than 10 is recommended as best suited to sampling coralligenous habitats by photographic methods. The total sampling area to be investigated for each study area with 10 replicates was $18750 \mathrm{~cm}^{2}$, which is in agreement with the total area suggested for western Mediterranean coralligenous habitats $\left(15000 \mathrm{~cm}^{2} \mathrm{ob}-\right.$ tained through three replicates of $5000 \mathrm{~cm}^{2}$, Kipson et al. 2011).

Differences between locations tens of kilometres apart were low, suggesting that coralligenous assem- blages show a homogeneous structure if subjected to similar environmental conditions, at least within the same geographic area. By contrast, coralligenous assemblages showed a high variability at small spatial scales, between plots one metre apart and areas hundreds of metres apart, while variability between sites several kilometres apart was very small. This finding agrees with results of previous studies (Ferdeghini et al. 2000, Piazzi et al. 2004, Balata et al. 2005, 2006b) and may reflect a patch distribution of organisms. Organism distribution in coralligenous habitats may be regulated by both substrate morphology and biotic interactions. In fact, the heterogeneity of biogenic substrate may create microhabitats characterized by different environmental conditions (Lapoint and Bourget 1999, Cocito 2004), which can influence the recruitment of spores and larvae (Walters and Wethey 1996). Moreover, the attenuation of effects of physical factors with depth leads to a greater influence of biotic factor in the control of assemblages. Competition for space is considered one of the main processes determining patterns of distribution in coralligenous habitats, where encrusting organisms compete intensely for substratum because they are limited to using space in only two dimensions (Balata et al. 2005). These findings suggest that sampling designs should focus on high replication at small scales, with little or no consideration of intermediate scales.

The assessment of the most suitable relation between the sampling area and the number of replicates is an interesting topic for coralligenous ecologists. Large organisms are usually studied using sampling areas (Kipson et al. 2011) or landscape approaches (Gatti et al. 2012), whereas phytobenthos is studied using a larger number of replicates (Acunto et al. 2001, Balata et al. 2005). The results of this study showed that the total sampling area detected for photographic samples agrees with that proposed by other studies (Kipson et al. 2011). The distribution of this area between samples and replicates may be an interesting goal for further research.

Summarizing the main results, impact evaluation on coralligenous assemblages may be effectively carried out through photographic samples larger than $1800 \mathrm{~cm}^{2}$, with a number of replicates larger than 10 , by using taxa/morphological groups as descriptors and planning sampling designs with a high replication at the small spatial scales. This kind of methodological procedures seems to be a good compromise between habitat conservation, scientific validity and time/cost effort requirements.

Concerning this latter aspect, photographic sampling reduces the time of field work and makes it possible to quickly collect the high number of samples required in a habitat with high variability at small spatial scales. It also involves relatively little laboratory analysis, reducing the time and cost of sorting and taxonomist work. However, photographic samplings require a longer time of image analysis than in situ visual methods (Parravicini et al. 2010b, Gatti et al. 2012). It is also important to optimize the sampling effort and the present study may provide useful information for 
optimizing monitoring programmes and impact evaluation studies in coralligenous habitats.

Although the study covered a limited geographical area, the results could provide basic information that can be integrated with data collected in other Mediterranean areas and in other studies using different approaches, in order to validate a sampling procedure applicable to the whole Mediterranean basin.

\section{ACKNOWLEDGEMENTS}

We wish to thank Joaquim Garrabou, Julie Deter and one anonymous referee, whose comments and suggestions have improved the manuscript. We also thank Angela Sarni for the English-Spanish translation

\section{REFERENCES}

Acunto S. 2000. Tecniche di campionamento fotografico e studio della variabilità spazio-temporale in popolamenti coralligeni. $\mathrm{PhD}$ thesis, University of Pisa.

Acunto S., Balata D., Cinelli F. 2001. Spatial variability in the coralligenous assemblage and evaluations of the sampling method. Biol. Mar. Medit. 8: 191-200.

Anderson M.J. 2001. A new method for a non-parametric multivariate analysis of variance. Austr. Ecol. 26: 32-46. http://dx.doi.org/10.1111/j.1442-9993.2001.01070.pp.x

Balata D., Piazzi L., Cecchi E., et al. 2005. Variability of Mediterranean coralligenous assemblages subject to local variation in sediment deposits. Mar. Environ. Res. 60: 403-421. http://dx.doi.org/10.1016/j.marenvres.2004.12.005

Balata D., Acunto S., Cinelli F. 2006a. Spatio-temporal variability and vertical distribution of a low rocky subtidal assemblage in the north-west Mediterranean. Estuar. Coast. Shelf Sci. 67: 553-561. http://dx.doi.org/10.1016/j.ecss.2005.12.009

Balata D., Acunto S., Piazzi L., et al. 2006b. Spatial variability of coralligenous assemblages. Biol. Mar. Medit. 13: 108-109.

Balata D., Piazzi L., Benedetti-Cecchi L. 2007a. Sediment disturbance and loss of beta diversity on subtidal rocky reefs. Ecology, 88: 2455-2461. http://dx.doi.org/10.1890/07-0053.1

Balata D., Piazzi L., Cinelli F. 2007b. Increase of sedimentation in a subtidal system: effects on the structure and diversity of macroalgal assemblages. J. Exp. Mar. Biol. Ecol. 351: 73-82. http://dx.doi.org/10.1016/j.jembe.2007.06.019

Balata D., Piazzi L., Rindi F. 2011. Testing a new classification of morphological functional groups of marine macroalgae for the detection or responses to disturbance. Mar. Biol. 158: 2459-2469. http://dx.doi.org/10.1007/s00227-011-1747-y

Ballesteros E. 2006. Mediterranean coralligenous assemblages: a synthesis of present knowledge. Oceanog. Mar. Biol. Annu. Rev. 44: 123-195.

Benedetti-Cecchi L. 2001a. Variability in abundance of algae and invertebrates at different spatial scales on rocky sea shores. Mar. Ecol. Progr. Ser. 215: 79-92. http://dx.doi.org/10.3354/meps215079

Benedetti-Cecchi L. 2001b. Beyond BACI: optimization of environmental sampling designs through monitoring and simulation. Ecol. Appl. 11: 783-799.

http://dx.doi.org/10.1890/1051-0761(2001)011[0783:BBOOE S]2.0.CO;2

Benedetti-Cecchi L., Airoldi L., Abbiati M., et al. 1996. Estimating the abundance of benthic invertebrates: a comparison of procedures and variability between observers. Mar. Ecol. Progr. Ser. 138: 93-101. http://dx.doi.org/10.3354/meps138093

Benedetti-Cecchi L., Bertocci I., Micheli F., et al. 2003. Implications of spatial heterogeneity for management of marine protected areas (MPAs): examples from assemblages of rocky coasts in the Northwest Mediterranean. Mar. Environ. Res., 55: 429-458. http://dx.doi.org/10.1016/S0141-1136(02)00310-0

Bianchi C.N., Pronzato R., Cattaneo-Vietti R., et al. 2004. Mediterranean marine benthos: a manual of methods for its sampling and study. 6: Hard bottoms. Biol. Mar. Medit. 11: 185-215.

Bishop M., Underwood A.J., Archambault P. 2002. Sewage and environmental impacts on rocky shores: necessity of identifying relevant spatial scales. Mar. Ecol. Progr. Ser. 236: 121-128. http://dx.doi.org/10.3354/meps236121

Boudouresque C.F. 1971. Méthodes d'étude qualitative et quantitative du benthos (en particulier du phytobenthos). Tethys 3 : 79-104.

Cecchi E., Piazzi L., Serena F. 2010. The use of coralligenous assemblages in the monitoring survey along the Tuscany coasts: the assessment of sampling procedures and results of five-years studies. Proceedings of the Third Symposium on Mediterranean Coastal Monitoring, CNR: 480-485.

Casellato S., Stefanon A. 2008. Coralligenous habitat in the northern Adriatic Sea: an overview. Mar. Ecol. 29: 321-341. http://dx.doi.org/10.1111/j.1439-0485.2008.00236.x

Chapman M.G. 1998. Relationships between spatial patterns of benthic assemblages in a mangrove forest using different levels of taxonomic resolution. Mar. Ecol. Progr. Ser. 162: 71-78. http://dx.doi.org/10.3354/meps162071

Cocito S. 2004. Bioconstruction and biodiversity: their mutual influence. Sci. Mar. 68: 137-144. http://dx.doi.org/10.3989/scimar.2004.68s1137

Cocito S., Sgorbini S., Bianchi C.N. 1997. Zonation of a suspension-feeder assemblage on a temperate rocky shoal: the influence of water current and bottom topography. In: Hawkins L.E., Hutchinson S. (eds), The response of marine organisms to their environments. University of Southampton, pp. 183-192.

Cocito S., Bedulli D., Sgorbini S. 2002. Distribution patterns of the sublittoral epibenthic assemblages on a rocky shoal in the Ligurian Sea (NW Mediterranean). Sci. Mar. 66: 175-181.

De Biasi A.M., Bianchi C.N., Morri C. 2003. Analysis of macrobenthic communities at different taxonomic levels: an example from an estuarine environment in the Ligurian Sea (NW Mediterranean). Estuar. Coast. Shelf Sci. 58: 99-106. http://dx.doi.org/10.1016/S0272-7714(03)00063-5

Deter J., Descamp P., Ballesta L., et al. 2012a. A preliminary study toward an index based on coralligenous assemblages for the ecological status assessment of Mediterranean French coastal waters. Ecol. Ind., 20: 345-352. http://dx.doi.org/10.1016/j.ecolind.2012.03.001

Deter J., Descamp P., Boissery P, et al. 2012b. A rapid photographic method detects depth gradient in coralligenous assemblages. J. Exp. Mar. Biol. Ecol. 418: 75-82. http://dx.doi.org/10.1016/j.jembe.2012.03.006

EC. 2000. DIRECTIVE 2000/60/EC of the European parliament and of the council, of 23 October 2000, establishing a framework for Community action in the field of water policy. Official Journal of the European Communities, G.U.C.E. 22/12/2000, L 327.

EC. 2008. DIRECTIVE 2008/56/EC of the European parliament and of the council, of 17 June 2008, establishing a framework for Community action in the field of marine environmental policy (Marine Strategy Framework Directive). Official Journal of the European Commission, G.U.C.E. 25/6/2008, L 164/19.

Ferdeghini F., Acunto S., Cocito S., et al. 2000. Variability at different spatial scales of a coralligenous assemblage at Giannutri island (Tuscan Archipelago, northwestern Mediterranean). Hydrobiologia 440: 27-36. http://dx.doi.org/10.1023/A:1004124423718

Fraschetti S., Terlizzi A., Benedetti-Cecchi L. 2005. Patterns of distribution of marine assemblages from rocky shore: evidence of relevant scales of variation. Mar. Ecol. Progr. Ser. 296: 13-29. http://dx.doi.org/10.3354/meps296013

Garrabou J., Sala E., Arcas A., et al. 1998. The impact of diving on rocky sublittoral communities: a case study of a bryozoan population. Conserv. Biol. 12: 302-312. http://dx.doi.org/10.1046/j.1523-1739.1998.96417.x

Garrabou, J., Ballesteros E., Zabala M. 2002. Structure and dynamics of northwestern Mediterranean rocky benthic communities along a depth gradient. Estuar. Coast. Shelf Sci. 55: 493-508. http://dx.doi.org/10.1006/ecss.2001.0920

Gatti G., Montefalcone M., Rovere A., et al. 2012. Seafloor integrity down the harbor waterfront: the coralligenous shoals off Vado Ligure (NW Mediterranean). Adv. Limnol. 3: 51-67. http://dx.doi.org/10.1080/19475721.2012.671190

Hewitt J.E., Thrush E., Cummings V.J. 2001. Assessing environmental impacts: effects of spatial and temporal variability at likely impact scales. Ecol. Appl. 11: 1502-1516. http://dx.doi.org/10.1890/1051-0761(2001)011[1502:AEIEOS ]2.0.CO;2 
Hirst A.J. 2006. Influence of taxonomic resolution on multivariate analyses of arthropod and macroalgal reef assemblages. Mar. Ecol. Prog. Ser. 324: 83-93. http://dx.doi.org/10.3354/meps324083

Hong J.S. 1982. Contribution à l'étude des peuplements d'un fond de concrétionnement Coralligène dans la région marseillaise en Méditerranée nord-occidentale. Bull. KORDI 4: 27-51.

Hong J.S. 1983. Impact of pollution on the benthic community. Environmental impact of the pollution on the benthic coralligenous community in the Gulf of Fos, north-western Mediterranean. Bull. Kor. Fish. Soc. 16: 273-290.

Jackson J.B.C. 1979. Morphological strategies of sessile animals. In: Larwood G., Rosen B.R. (eds), Biology and systematic of colonial organisms. Academic Press, pp. 499-555.

Kipson S., Fourt M., Teixido N., et al. 2011. Rapid Biodiversity Assessment and Monitoring Method for Highly Diverse Benthic Communities: A case Study of Mediterranean Coralligenous Outcrops. PLoS One 6: e27103. http://dx.doi.org/10.1371/journal.pone.0027103

Konar B., Iken K. 2009. Influence of taxonomic resolution and morphological functional groups in multivariate analyses of macroalgal assemblages. Phycologia 48: 24-31. http://dx.doi.org/10.2216/08-12.1

Laborel J. 1961. Le concrétionnement algal "coralligene" et son importance geomorphologique en Méditerranée. Trav. Sci. Stat. Mar. Endoume. 23: 37-60.

Laborel J. 1987. Marine biogenic constructions in the Mediterranean, a review. Sci. Rep. Port-Cros nat. Park 13: 97-127.

Laubier L. 1966. Le coralligène des Albères. Monographie biocenotique. Ann. Inst. Oceanogr. Paris 43: 137-316.

Lapoint L., Bourget E. 1999. Influence of substratum heterogeneity scales and complexity on a temperate epibenthic marine community. Mar. Ecol. Progr. Ser. 189: 159-170. http://dx.doi.org/10.3354/meps189159

Littler M.M., Littler D.S. 1980. The evolution of thallus form and survival strategies in benthic marine macroalgae: field and laboratory tests of a functional form model. Am. Nat. 116: 25-44. http://dx.doi.org/10.1086/283610

Parravicini V., Morri C., Ciribilli G., et al. 2009. Size matters more than method: visual quadrats vs photography in measuring human impact on Mediterranean rocky reef communities. Estuar. Coast. Shelf Sci. 81: 358-367. http://dx.doi.org/10.1016/j.ecss.2008.11.007

Parravicini V., Guidetti P., Morri C., et al. 2010a. Consequences of sea water temperature anomalies on a Mediterranean submarine cave ecosystem. Estuar. Coast. Shelf Sci. 86: 276-282. http://dx.doi.org/10.1016/j.ecss.2009.11.004

Parravicini V., Micheli F., Montefalcone M., et al. 2010b. Rapid assessment of benthic communities: a comparison between two visual sampling techniques. J. Exp. Mar. Biol. Ecol. 395: 21-29. http://dx.doi.org/10.1016/j.jembe.2010.08.005

Parravicini V., Micheli F., Montefalcone M., et al. 2013. Conserving biodiversity in a human-dominated world: degradation of marine sessile communities within a protected area with conflicting human uses. PLoS One, 8: e75767. http://dx.doi.org/10.1371/journal.pone.0075767

Phillips J.C., Kendrick G.A., Lavery P.S. 1997. A test of a functional group approach to detecting shift of macroalgal communities along a disturbance gradient. Mar. Ecol. Progr. Ser. 153: $125-138$.

http://dx.doi.org/10.3354/meps 153125

Piazzi L, Balata D. 2011. Coralligenous habitat: patterns of vertical distribution of macroalgal assemblages. Sci. Mar. 75: 399-406. http://dx.doi.org/10.3989/scimar.2011.75n2399
Piazzi L., Balata D., Pertusati M., et al. 2004. Spatial and temporal variability of Mediterranean macroalgal coralligenous assemblages in relation to habitat and substrate inclination. Bot. Mar. 47: $105-115$. http://dx.doi.org/10.1515/BOT.2004.010

Piazzi L., Balata D., Cinelli F. 2007. Invasions of alien macroalgae in Mediterranean coralligenous assemblages. Cryptogamie Algol. 28: 289-301

Piazzi L., Balata D., Cecchi E., et al. 2010. Species composition and patterns of diversity of macroalgal coralligenous assemblages of northwester Mediterranean Sea. J. Nat. Hist. 44: 1-22. http://dx.doi.org/10.1080/00222930903377547

Piazzi L., Gennaro P., Balata D. 2011. Effects of nutrient enrichment on macroalgal coralligenous assemblages. Mar. Pollut. Bull. 62: 1830-1835. http://dx.doi.org/10.1016/j.marpolbul.2011.05.004

Piazzi L., Gennaro P., Balata D. 2012. Threats to macroalgal coralligenous assemblages in the Mediterranean Sea. Mar. Pollut. Bull. 64: 2623-2629. http://dx.doi.org/10.1016/j.marpolbul.2012.07.027

Ponti M., Fava F., Abbiati M. 2011. Spatial-temporal variability of epibenthic assemblages on subtidal biogenic reefs in the northern Adriatic Sea. Mar. Biol. 158: 1447-1459. http://dx.doi.org/10.1007/s00227-011-1661-3

Roghi F., Parravicini V., Montefalcone M., et al. 2010. Decadal evolution of a coralligenous ecosystem under the influence of human impacts and climate change. Biol. Mar. Medit. 17: 59-62.

Steneck R.L., Dethier M.N. 1994. A functional group approach to the structure of algal-dominated communities. Oikos 69: 476-498 http://dx.doi.org/10.2307/3545860

Teixido N., Casas E., Cebrian E., et al. 2013. Impacts on coralligenous outcrop biodiversity of a dramatic coastal storm. PLoS One 8(1): e53742. http://dx.doi.org/10.1371/journal.pone.0053742

Terlizzi A., Bevilacqua S., Fraschetti S., et al. 2003. Taxonomic sufficiency and the increasing insufficiency of taxonomic expertise. Mar. Pollut. Bull. 46: 556-561. http://dx.doi.org/10.1016/S0025-326X(03)00066-3

Terlizzi A., Anderson M. J., Fraschetti S., et al. 2007. Scales of spatial variation in Mediterranean subtidal sessile assemblages at different depths. Mar. Ecol. Progr. Ser. 332: 25-39. http://dx.doi.org/10.3354/meps332025

Underwood AJ. 1993. The mechanics of spatially replicated sampling programs to detect environmental impacts in a variables world. Aust. J. Ecol. 18: 99-116. http://dx.doi.org/10.1111/j.1442-9993.1993.tb00437.x

Underwood A.J., Chapman M.G. 1996. Scales of spatial patterns of distribution of intertidal invertebrates. Oecologia 107: 212-224 http://dx.doi.org/10.1007/BF00327905

UNEP. 2007. Draft decision on the "Action plan for the protection of the coralligenous and other calcareous bio-concretions in the Mediterranean". UNEP (DEPI)/MED WG.320/20, 2 pp + Annex.

Walters L.J., Wethey D.S. 1996. Settlement and early post-settlement survival of sessile marine invertebrates on topographically complex surfaces: the importance of refuge dimensions and adult morphology. Mar. Ecol. Progr. Ser. 137: 161-171. http://dx.doi.org/10.3354/meps 137161

Virgilio M., Airoldi L., Abbiati M. 2006. Spatial and temporal variations of assemblages in a Mediterranean coralligenous reef and relationships with surface orientation. Coral Reefs 25: 265-272. http://dx.doi.org/10.1007/s00338-006-0100-2 
Appendix 1. - List of taxa identified in the destructive samples. Groups used in the photographic samples are indicated when taxa were not considered at the species level. Species identified with photographs are indicated with an asterisk.

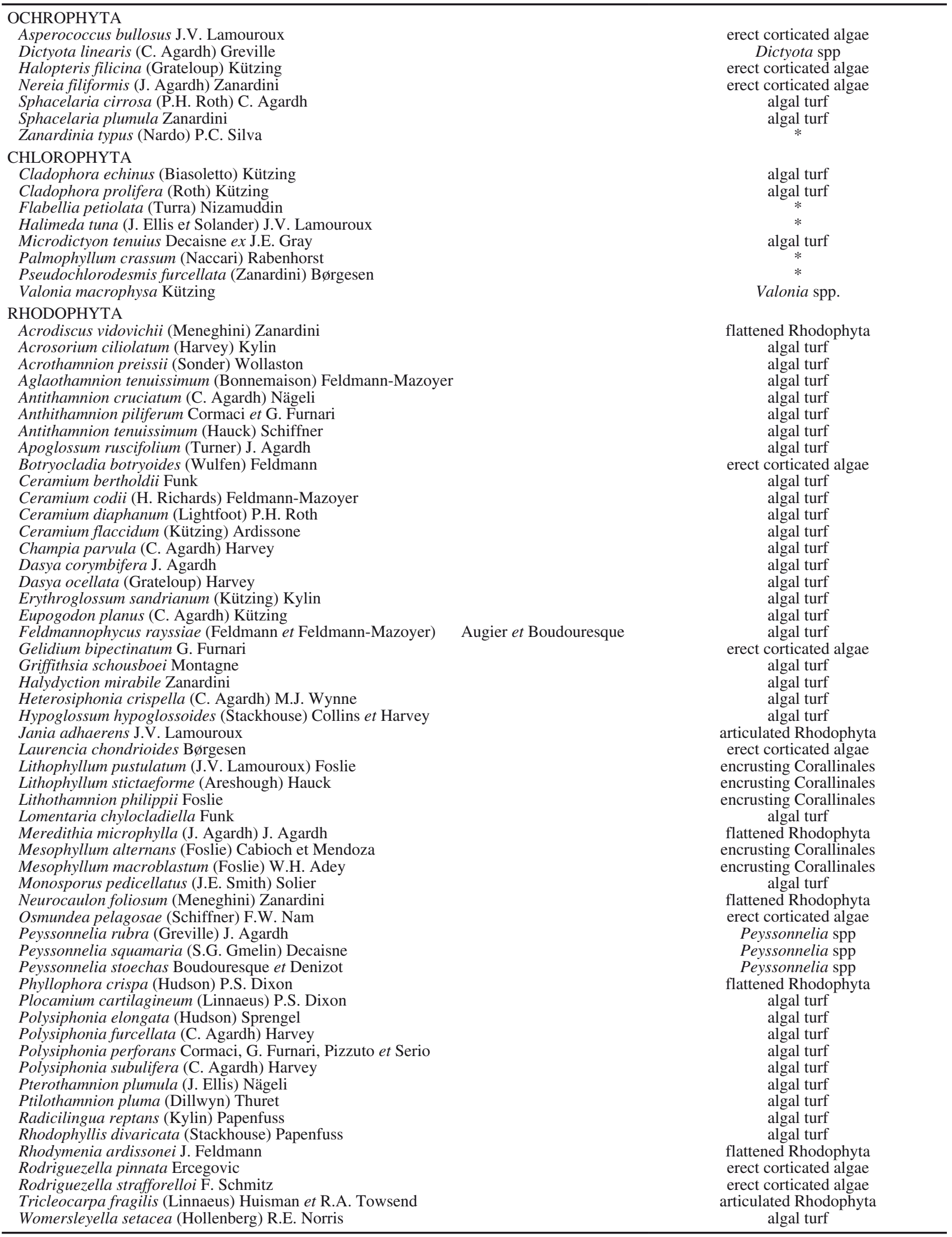




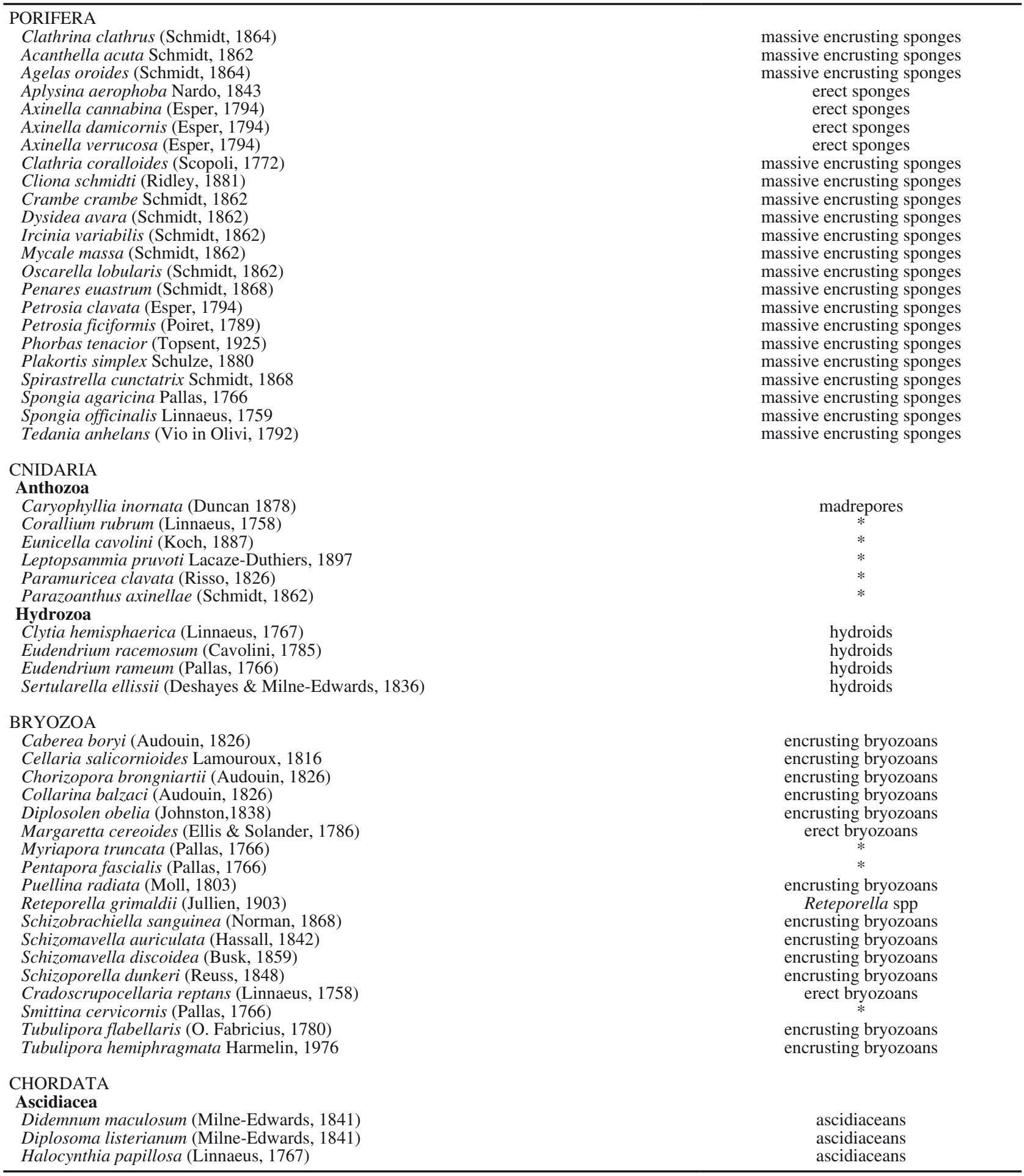

